S, PEKKER

A, JANNOSSY

THREE DIMENSIONALLY ORIENTED POLYACETYLENE

Hungarian Academy of Sciences CENTRAL RESEARCH INSTITUTE FOR PHYSICS 


\title{
THREE DIMENSIONALLY ORIENTED POLYACETYLENE
}

\author{
S. Pekker and A. Jánossy \\ Central Research Institute for Physics \\ H-1525 Budapest 114, P.O.B. 49, Hungary
}




\section{ABSTRACT}

Changes in the dimensions of oriented polyacetylene under isomerisation and lodine doping are presented. We show that the polymer chains are parallel to the fiber axis. In roll-oriented samples the relative change in dimensions in anisotropic in all three directions and this is attributed to an ordering of the fibers with respect to the crystalline axes of the polymer. The volume depends linearly on iodine concentration in agreement with a model of inhomogeneous doping where it is assumed that for intermediate iodine concentrations the fibers consist of a fully doped surface layer surrounding the undoped interiour.

\section{АНнОТАЦИЯ}

Исследовались изменения размера ориентированного полиацетилена при изомеризации и легировании иодом. Было показано, что цепи полимера параллельны оси волокон. Относительное изменение размера ориентированных прокаткой образзов во всех трех направлениях является анизотропическим, что объясняется упорядочением волокон в направлении кристаллических осей полимера. Объем образца линейно зависит от концентрации иода, соответственно модели негомогенного легирования, предполагаюпей, что при средних концентрациях иода волокна состоят из полностью легированного внешнего слоя, окружающего нелегированную внутренность волокон.

\section{KIVONAT}

Orientált poliacetilén izomerizáció és jód adalékolás hatására történõ méretváltozásait közöljük. Megmutatjuk, hogy a polimer láncok a szálak tengelyével párhuzamosak. Hengerléssel orientált minták relativ méretváltozása mindhárom irányban anizotróp, ami annak tulajdonsitható, hogy a szálak a polimer kristálytani tengelyeinek megfelelõen renciezõdnek. A térfogat lineárisan függ a jódkoncentrációtól, összhangban az inhomogén adalékolásra vonatkozó modellel, miszerint közbủlsõ koncentrációknál a szálak belseje jódozatlan, amit teljesen megjódozott felületi réteg vesz körül. 


\section{INTRODUCTION}

Doped polyacetylene (PA) is a highly conducting polymer with strongly anisotropic properties when the polymer chains are oriented." Host experiments on it have been performed on microcrystalline films prepared by the method of Shirakawa et al. [1]. The films consist of loosely packed fibers with an average diameter of $200 \AA$ [2]. PA has two geometric isomers with different structures and properties. The crystal structure of the cis and trans isomers and the doped derivatives have been determined by $\mathrm{x}$-ray diffraction combined with a packing analysis $[3,4,5]$.

The type of the PA crystallites and their orientation within the fibers have raised some controversy. The fibrous structure is usually a sign of the applicability of the fringed micellar model according to which the polymer chains are quasi-parallel to the fiber axis. This extended chain structure, suggested by Shirakawa et al. $[1,6]$, is consistent with the anisotropy observed in optical [7], electric transport [2], and dielectric [8] properties.

On the other hand Lieser et al. reported electron diffraction measurements [9] according to which the fibers consist of aggregated chain-folded lamellae with the average chain direction nearly perpendicular to the fiber axis.

The dimensional change measurements presented here confirm the fringed micellar structure. Mechanic rolling gives rise to an ordering of the fibrous crystallites in all three directions i.e. in addition to the alignment along the rolling direction in the plane perpendicular to it. We find a linear dependence of the volume with iodine content in agreement with a recently suggested model of inhomogeneous doping [10]. 


\section{EXPERIMENTAL}

Cis-rich PA films were prepared by the method of Shirakawa et al. [1] at $-78^{\circ} \mathrm{C}$. Films were oriented by different methods: a) samples were stretched during thermal isomerisation in a device similar to that described by Shirakawa et al. [2]; b) other samples were rolled in a simple rolling device at room temperature; c) part of the stretch-oriented samples were subsequently rolled. The elongation ratio in all cases was $1 / 11_{0} 2.5$. The rolled cis samples were isomerized at $180^{\circ} \mathrm{C}$ for 20 minutes under vacuum.

Iodination of the oriented trans samples was carried out at room temperature under iodine atmosphere for different times. The reaction was interrupted from time to time and the weight and three sizes of the samples were measured by a microbalance and a measuring microscope respectively. The initial sample dimensions were about $10 \times 3 \times 0.04 \mathrm{~mm}^{3}$ and the density of rolled samples was $\rho_{\mathrm{O}} \approx 1.02 \mathrm{~g} / \mathrm{cm}^{3}$. During isomerization and iodine doping the PA films were kept between two glass frits to prevent distortion.

\section{RESULTS AND DISCUSSION}

The relative changes in dimensions of mechanically rolled PA when isomerized from the cis to the trans form are:

$$
\frac{\Delta i}{i_{0}}=0.00 \pm 0.03, \quad \frac{\Delta j}{j_{0}}=-0.022 \pm 0.001 \text { and } \frac{\Delta k}{k_{0}}=0.043 \pm 0.001
$$

where $i$ is the thickness, $j$ the width and $k$ the length of the sample, $i$ and $j$ are perpendicular and $k$ is parallel to the rolling direction (Fig. 1) $i_{0} j_{0}$ and $k_{0}$ are the initial dimensions. The increase of the length $k$ is consistent with the results of Druy et al. [11]. The trans isomer chain length is longer than that of the cis isomer while their densities are nearly the same. Both rolling and stretching aligns the fibers preferentially along $\mathrm{k}$ which is the direction in which the size increased during isomeri-- 
zation. Thus we conclude that the PA molecular chains are directed along the fiber axis as expected for a fringed micellar structure. The increase of $\mathrm{k}$ calculated for an ideal single crystal is between $\Delta \mathrm{k}_{\mathrm{k}} \mathrm{k}_{\mathrm{o}}=0.1-0.2$ from $\mathrm{X}$-ray [5] and electron microscopic [12] studies, much higher than the measured value of 0.043 . Incomplete orientation of the fibers is unlikely to be the only reason for the discrepancy since the same samples show highly anisotropic dimensional changes upon iodination as presented below. An other reason may be that the starting material was partly isomerized by the rolling $[8]$.

Figure 1 shows the relative dimensional changes of trans PA oriented in different ways as a function of lodine content $y$, defined by the formula $\left(\mathrm{CHI}_{\mathrm{y}}\right)_{\mathrm{x}}$. The sizes perpendicular to the direction of elongation increase while the parallel one decreases upon iodine doping. The high anisotropy of the changes in the parallel and the two perpendicular directions show the high degree of orientation of the fibers. The increase of the sizes $i$ and $j$ supports the fringed micellar model discussed above. In this model the fiber axes, which are directed mainly along $k$ are in the crystallographic $b$ axis $1 . e$. the chain direction. According to the $\mathrm{X}$-ray studies of Baughman et al. [4], iodine intercalates into the close-packed PA planes containing this direction. Thus the experimentally found near doubling of the sum of the sizes in the $i$ and $j$ directions gives a strong support to this model. It also points to the high degree of orientation of the fibers. The increase for stretched samples is somewhat less than for rolled ones probably because the packing of the fibers becomes somewhat tighter in the doped material.

The dimensional changes along the direction of elongation are similar for all types of samples. On the other hand the sizes perpendicular to the direction of elongation increase depending on the way of orientation. The increase of the sizes $i$ and $j$ of the samples only stretched measured at $y=0.25$ iodine content are 
$\Delta i / i_{0}=0.20$ and $\Delta j / j_{0}=0.18$ (Fig. 1). These values, in agreement with those of Druy et al. [11], do not show any important difference between the directions $i$ and $j$. At the same time the increases in these two directions are strongly differing when samples are rolled. As shown on Figure 1 the increase of the thickness (i) is about 4.5 times more than that of the width $(j)$. If the fiber axes had an appreciable component along $i$ and/or $j$ an increase in the size $\mathrm{k}$ would occur. Since the size $\mathrm{k}$ decreases we assume that the orientation is nearly complete along it thus $\underline{b}=\underline{k}$, where $\underline{b}$ and $\underline{k}$ are unit vectors parallel to the polymer chain direction and the direction of the elongation respectively. Also in the $\underline{c}$ direction no dimensional increase is expected, thus from the measured anisotropy in the (i, $\underline{j})$ plane we find:

$$
\begin{aligned}
& \underline{a}=0.98 \underline{\underline{i}}+0.22 \underline{j} . \\
& \underline{c}=0.22 \underline{\underline{i}}+0.98 \underline{j}
\end{aligned}
$$

where $\underline{a}$ and $\underline{c}$ are unit vectors parallel to the crystallographic axes evaluated by Baughman et al. [4] i.e. ac is perpendicular to the chain direction ( $\underline{b}), \underline{b c}$ is the close-packed plane, $\underline{i}$ and $\underline{j}$ are unit vectors parallel to the $i$ and $j$ sides of the film respectively. Thus rolled polyacetylene is highly oriented in all three directions. The orientation in the $\underline{a}$ and $\underline{c}$ crystallographic directions can result from the pressure of the rolls since the interchain forces are different in the two directions.

The decrease of the size k (Fig. 1) can not be understood by models in which the chain lengths remain unchanged. For example distortion of cross-linked chains due to iodine intercalation would result in a far too small decrease of the length parallel to the chains to be consistent with the observed effect. The effect is an intrinsic shortening of the chains due to iodine doping. The electronic structues of pure and iodine doped PA are substantially different and changes in the molecular geometries are conceivable. The main effect is probably the decrease of the 
C-C-C bond angles. X-ray diffraction data [5] were probably too much limited by the poor quality of the doped crystals to reveal this.

Figure 2 shows the volume dependence on iodine content of doped PA normalized to the unit mass of pure samples. The volume of high density (rolled) trans PA increases linearly with y. A somewhat different variation of the volume with iodine concentration was found by Francois et al. [13] on low density samples. A linear dependence of the volume on iodine concentration is expected if doping is inhomogeneous in the way suggested by Janossy et al. [10]. It was suggested that incompletely doped PA is separated into pure and fully doped phases probably within each fiber. Only the volume ratio of the two phases change during doping. The dependence of the volume on iodine concentration can be calculated on the basis of this model:

$$
\frac{\mathrm{V}}{\mathrm{m}_{\mathrm{o}}}=\frac{1}{\rho_{\mathrm{o}}}\left(1+\frac{\mathrm{y}}{\mathrm{y}_{\mathrm{m}}} \frac{\mathrm{a}_{\mathrm{I}}-\mathrm{a}_{\mathrm{O}}}{\mathrm{a}_{I}}\right)
$$

where $\mathrm{V}$ is the volume of iodine doped PA, $\mathrm{m}_{\mathrm{O}}$ is the initial mass, $\rho_{0}=1.16 \mathrm{~g} / \mathrm{cm}^{3}$ the density of $\mathrm{PA}, \mathrm{y}$ is the iodine concentration, $y_{m}=0.33$ the iodine concentration of the fully doped phase, $a_{I}=7.75 \AA$ and $a_{0}=3.75 \AA$ the close packed plane spacings of iodinated and pure PA respectively [4]. The full line on Fig. 2 shows calculated values of $\mathrm{V} / \mathrm{m}_{0}$. The difference between the measured and calculated values is $0.1 \mathrm{~cm}^{3} / \mathrm{g}$ independently of the iodine content. This excess volume corresponds to the integrated pore volume remaining in the samples after rolling. The good agreement between the measured and calculated data and in particular the observed linear dependence of $V$ on $y$ confirm the phase separation in incompletely doped PA. If the doping were homogeneous a nonlinear dependence would be expected, a fast increase at low concentrations and a relatively slower increase at high concentrations. 
In conclusion we have shown that in polyacetylene the polymer chains are oriented parallel to the fiber axis. Rolling orders three dimensionally the PA crystallites as evidenced by the anisotropy of dimensional changes of doped PA. The decrease of the dimension parallel to the elongation probably reflects an intrinsic shortening of PA chains in the doped material. The linear dependence of the volume on iodine content can be explained by the model of a phase separation to pure and fully doped PA.

\section{REFERENCES}

[1] T.Ito, H.Shirakawa and S.Ikeda, J.Polym.Sci.Polym.Chem.Ed. 12,11 (1974)

[2] H.Shirakawa and S.Ikeda, Synth.Met. 1, 175 (1979/80)

[3] S.L.Hsu, A.J.Signorelli, G.P.Pez and R.H.Baughman, J.Chem. Phys. 69, 106 (1978)

[4] R.H.Baughman, S.L.Hsu, G.P.Pez and A.J.Signorelli, J.Chem. Phys. 68, 5405 (1978)

[5] R.H.Baughman, S.L.Hsu, L.R.Anderson, G.P.Pez and A.J. Signorelli, Molecular Metals, NATO Conf. Ser., W.E.Hatfield Editor, p.187 (Plenum Press, 1979)

[6] T.Akaishi, K.Miyasaka, K.Ishikawa, H.Shirakawa and S.Ikeda, J.Polym.Sci.Polym.Phys.Ed. 18, 745 (1980)

[7] C.R.Fincher, Jr., D.L.Peebles, A.J.Heeger, M.A.Druy, Y.Matsumura, A.G.MacDiarmid, H.Shirakawa and S.Ikeda, Solid State Commun. 27, 489 (1978)

[8] F.Devreux, I.Döry, L.Mihally, S.Pekker, A.Janossy and M.Kertesz, J.Polym.Sci.Polym.Phys.Ed. 19, 743 (1981)

[9] G.Lieser, G.Wegner, W.Mủller, V.Enkelmann, Makromol.Chem., Rapid Commun. 1, 621 (1980)

[10] A.Jánossy, L.Pogány, S.Pekker and R.Swietlik, to be published

[11] M.A.Druy, C.M.Tsang, N.Brown, A.J.Heeger and A.G.MacDiarmid, J.Polym.Sci.Polym.Phys.Ed. 18, 429 (1980)

[12] G.Lieser, G.Wegner, W.Müller, V.Enkelmann, Macromol.Chem., Rapid Commun. 1, 627 (1:980)

[13] B.Francois, N.Mermilliod and L.Zuppiroli, to be published 


\section{FIGURE CAPTIONS}

Figure 1: Relative changes in dimensions of oriented trans polyacetylene as a function of iodine content ( $y$ ) -: rolled, $\mathrm{x}$ : stretched and rolled, $\mathbf{m}$ : stretched samples

$k$ is the direction of elongation

Figure 2: Volume dependence on iodine content (y) of doped polyacetylene normalized to the unit mass of undoped samples

- : rolled, $\mathrm{x}$ : stretched and rolled samples

full line: calculated from expression (1) 


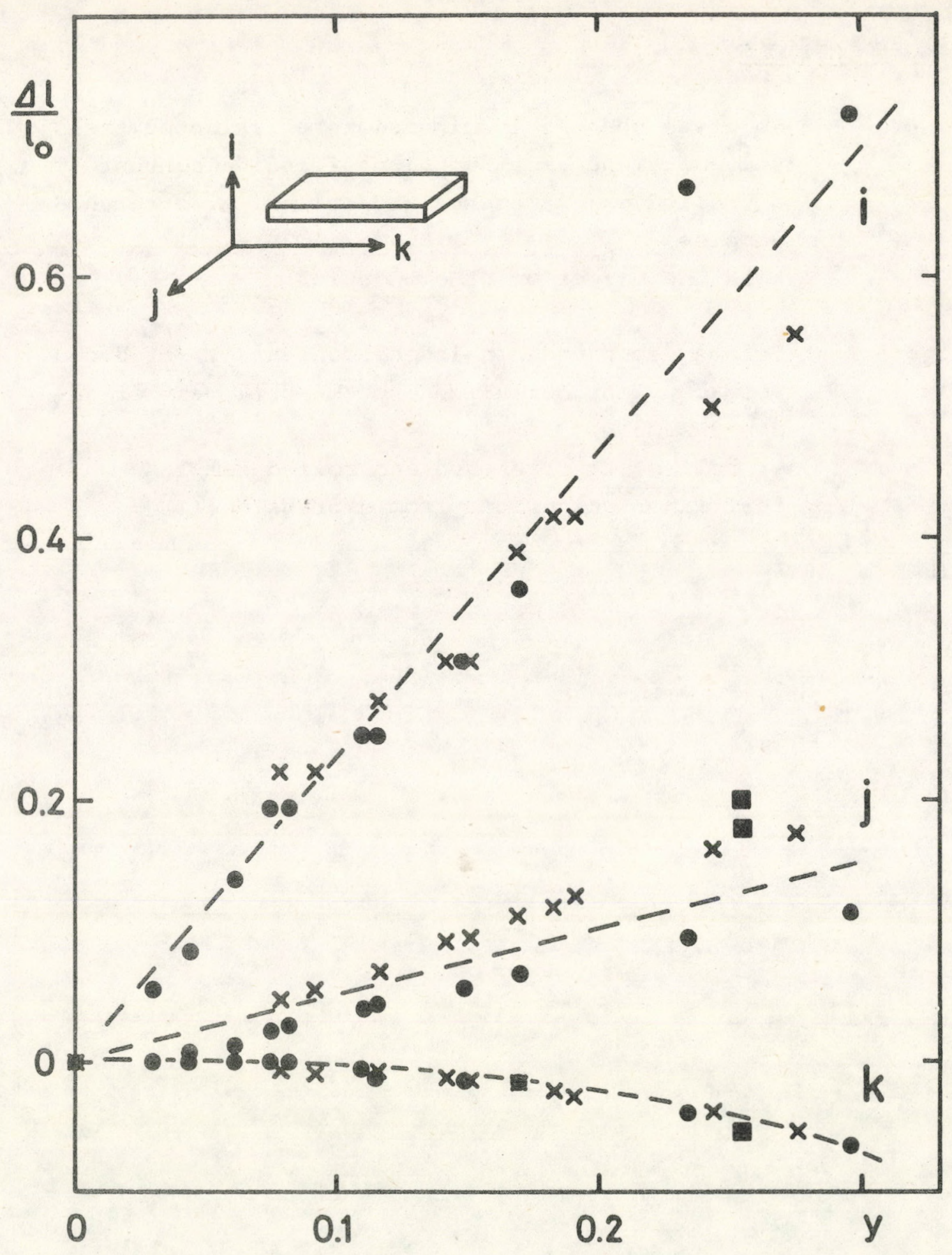

Fig. 1 


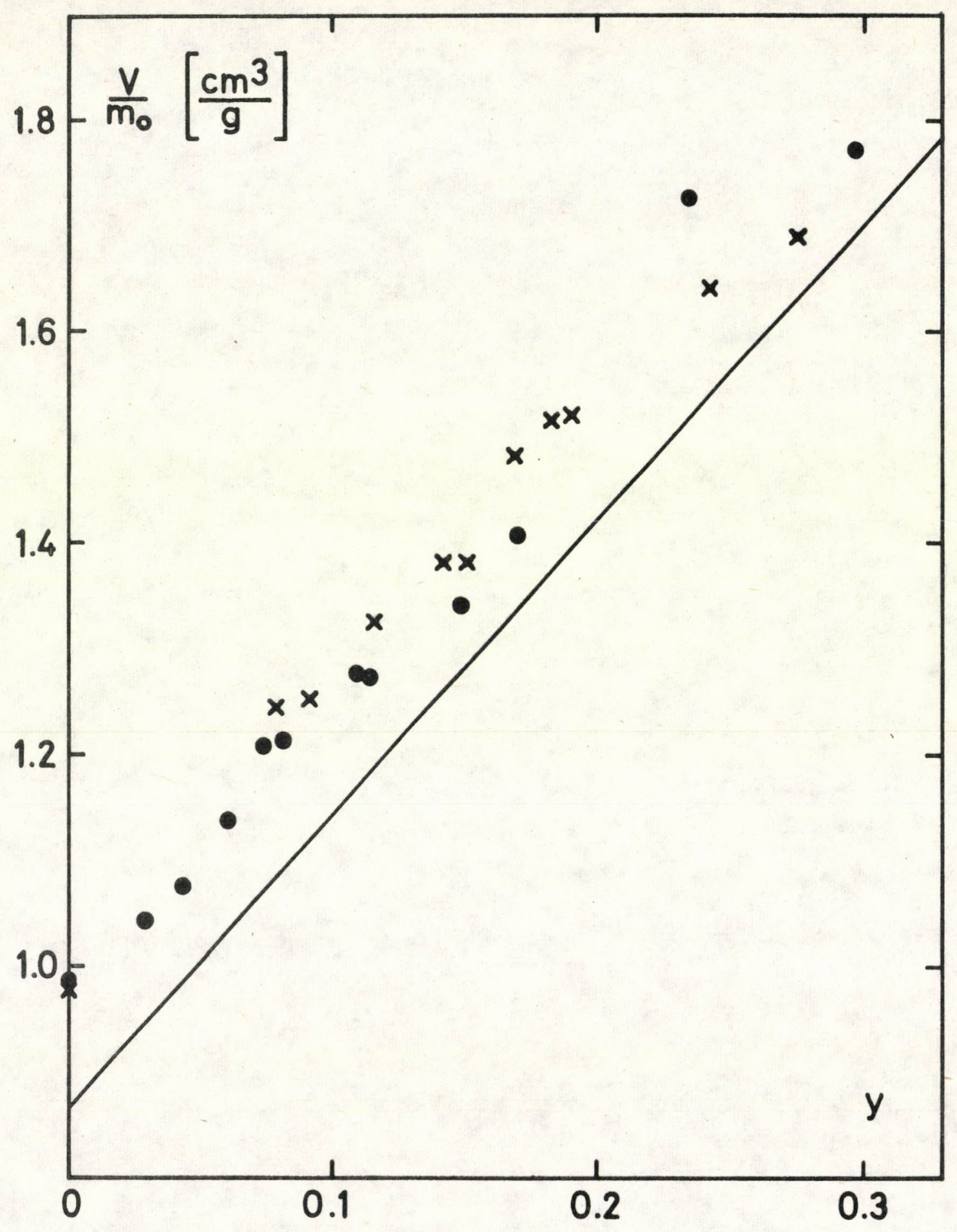

Fig. 2 



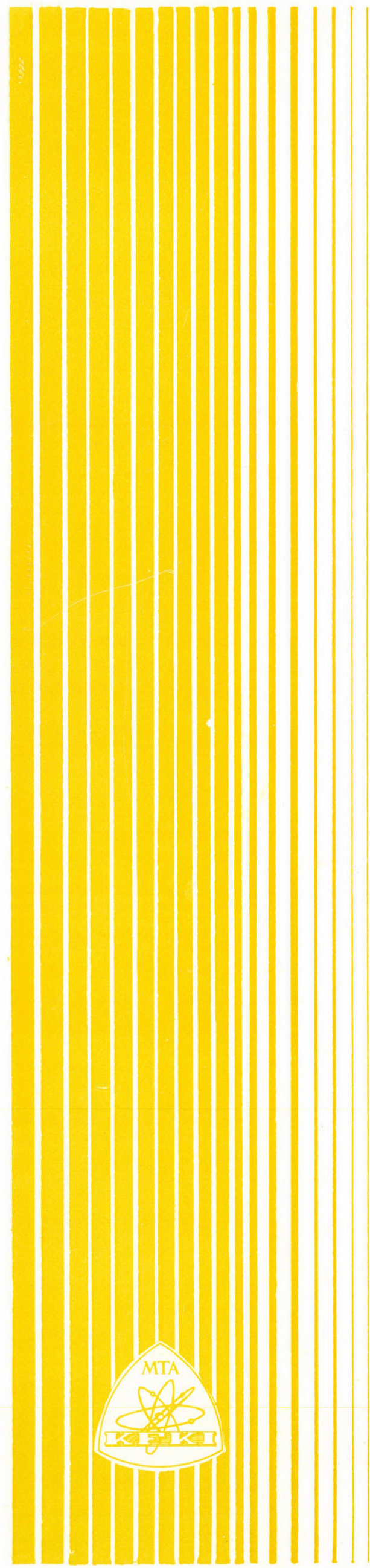

Kiadja a Központi Fizikai Kutató Intézet Felelôs kiadó: Kroó Norbert

Szakmai lektor: Mihály György

Nyelvi lektor: Mihály György

példányszám: 520 Törzsszám: 81-360

Készült a KFKI sokszorositó üzemében

Felelôs vezetõ: Nagy Károly

Budapest, 1981. junius hó 